Article

\title{
Toward Decision-Making Support: Valuation and Mapping of New Management Scenarios for Tunisian Cork Oak Forests
}

\author{
Mariem Khalfaoui ${ }^{1,2, *}$, Hamed Daly-Hassen ${ }^{1}$, Boutheina Stiti ${ }^{1}{ }^{(D)}$ and Sihem Jebari ${ }^{1}$ \\ 1 National Institute of Research in Rural Engineering, Water and Forests, University of Carthage, B.P. 10, \\ Ariana 2080, Tunisia; hamed.daly1@gmail.com (H.D.-H.); stitibou@gmail.com (B.S.); \\ sihem.jebari@gmail.com (S.J.) \\ 2 National Institute of Agronomy of Tunis, University of Carthage, 43 Avenue Charles Nicolle, \\ Tunis 1082, Tunisia \\ * Correspondence: khalfaouimaryem@gmail.com; Tel.: +216-93151885
}

Received: 31 October 2019; Accepted: 18 January 2020; Published: 11 February 2020

\begin{abstract}
Forest ecosystems are an important anthropogenic pillar to human wellbeing, providing a multitude of ecosystem services. In Mediterranean countries, where climate change effects are exponentially increasing, the value of the forest ecosystem services is even higher and their preservation is more crucial. However, the biophysical and economic value of such services is usually not observable due to their non-marketable characteristics, leading to their underestimation by decision-makers. This paper aims to guide decision-making through a set of new management scenarios based on ecosystem services' values and their spatial distribution. It is a cumulative multidisciplinary study based on biophysical models results, economically valued and implemented using the geographic information system (GIS) to analyze spatial data. The investigation was based on a biophysical and economic valuation of cork, grazing, carbon sequestration and sediment retention as a selection of ecosystem services provided by cork oak forest (Ain Snoussi, Tunisia). The valuation was made for the actual situation and two management scenarios (density decrease and afforestation of the shrub land), with emphasis on their spatial distribution as a basis to new management. The total economic value (TEV) of the investigated services provided by Ain Snoussi forest ( $3787 \mathrm{ha}$ ) was $€ 0.55$ million/year corresponding to $€ 194 / \mathrm{ha} /$ year. The assessment of two different scenarios based on the land cover changes showed that the afforestation scenario provided the highest TEV with $€ 0.68$ million/year and an average of $€ 217 / \mathrm{ha}$, while the density decrease scenario provided $€ 0.54$ million/year and an average of $€ 191 /$ ha. Such results may orient decision-makers about the impact new management may have, however they should be applied with caution and wariness due to the importance of the spatial dimension in this study.
\end{abstract}

Keywords: ecosystem services; economic valuation; mapping; management scenarios; Tunisia

\section{Introduction}

Considered an evolving concept, the ecosystem services (ES) approach appeared in the 1970s with a visionary objective based on increasing concern about the vulnerability of nature. The concept appeared to attract policymakers' attention and enhance their awareness about the future risks to be faced [1]. However, more recently the ES studies' objectives have evolved from warning policy makers about the extinction risks and the need to conserve biodiversity [2], to the integration of ES into decision-making processes, considering conservation only as an option and aiming for more relevant and sustainable management $[3,4]$. The fact that ecosystem services have indirect effects on human well-being, and that their value is usually unobservable, leads to their underestimation. The economic 
assessment can be traced back to the 70s [5], when scientists started fearing and wondering about species' extinction and the effect it might have on human well-being, and began thinking about a way to replace them $[1,6,7]$. However, it gained international attention with Costanza's publication in 1997 "The value of the world's ecosystem service", defining ES as benefits that human populations derive directly or indirectly from ecosystems [8], where the interest in the economic approach to ecosystem services valuation was intended to "stress societal dependence on natural ecosystems and raise public interest on biodiversity conservation" [2]. A clear distinction could be perceived in ES's values based on their usage criteria. A distinction that has been used since 1975, dividing values into use and non-use generally summarized in what is actually called total economic value (TEV), a framework commonly applied in economic valuation studies [9-11]. According to Hanley's explanation, the "use value" requires direct or indirect participation to benefit from the ES as a source of utility and it can be consumptive or non-consumptive [12]. However, non-users may also benefit from ES either from considering a potential future use "option value", or by knowing such a service exists "existence value", or by being altruistic and according a value to the service to keep it for future generation "bequest value" [9].

The appearance of the ecosystem services concept and their economic value has been followed by several efforts to understand, define, classify [13,14], and evaluate ecosystem services [15-19]. According to the most recent classification by the Common International Classification for Ecosystem Services (CICES) [20], ecosystem services are divided into three main sections: provisioning, regulating and cultural. Although this classification has been described as the gate to a wider understanding and use of ES [18], the importance of these values is not regularly observable as they refer to material or non-material values (material values in relation to provisioning and regulating services; non-material values and/or benefits associated with cultural services).

Based on the Intergovernmental Science Policy Platform on Biodiversity and Ecosystem Services (IPBES) approach and considering the existence of two world views, anthropocentric and non-anthropocentric, the TEV summarizes only a part of an ecosystem's value based on the anthropocentric concept valuing the so-called "nature's benefits to people" [21]. More recently, and for the same purpose of providing a better decision-making guidance, the interest in spatial ecosystem assessment has increased, aiming to combine the assessment of biophysical, economic, and social context while taking into consideration the spatial distribution of ES [22].

In this study, the forest area of Ain Snoussi was considered as a case study. Provisioning services (cork and grazing) and regulation services (carbon sequestration and sediment retention) were selected, among other ecosystem services provided by the forest, based on their economic importance as determined in previous studies [23]. The total economic value "TEV" refers to the total economic value of investigated services. The objective of the present work was to support decision-making through the valuation and mapping of a selection of ecosystem services in order to maximize forests value. The study was based on (i)a valuation of the total economic value with a distinction between the different land covers in the area, followed by (ii) mapping the results of the valuation, (iii) economic valuation of new management scenarios based on the results of several meetings with stakeholders, and (iv) discussion and establishment of the most adequate recommendation for a better management decision-making guidance.

\section{Materials and Methods}

\subsection{Case Study}

The site is located at the eastern limit of the Kroumirie region in north-western Tunisia, as shown in Figure 1. Ain Snoussi forest was chosen as representative site for Tunisian cork oak forests suffering from both anthropogenic and non-anthropogenic pressures. Several research projects and studies had already been conducted in the area, making the choice of the site justified and allowing access to a wide range of useful data and information. 


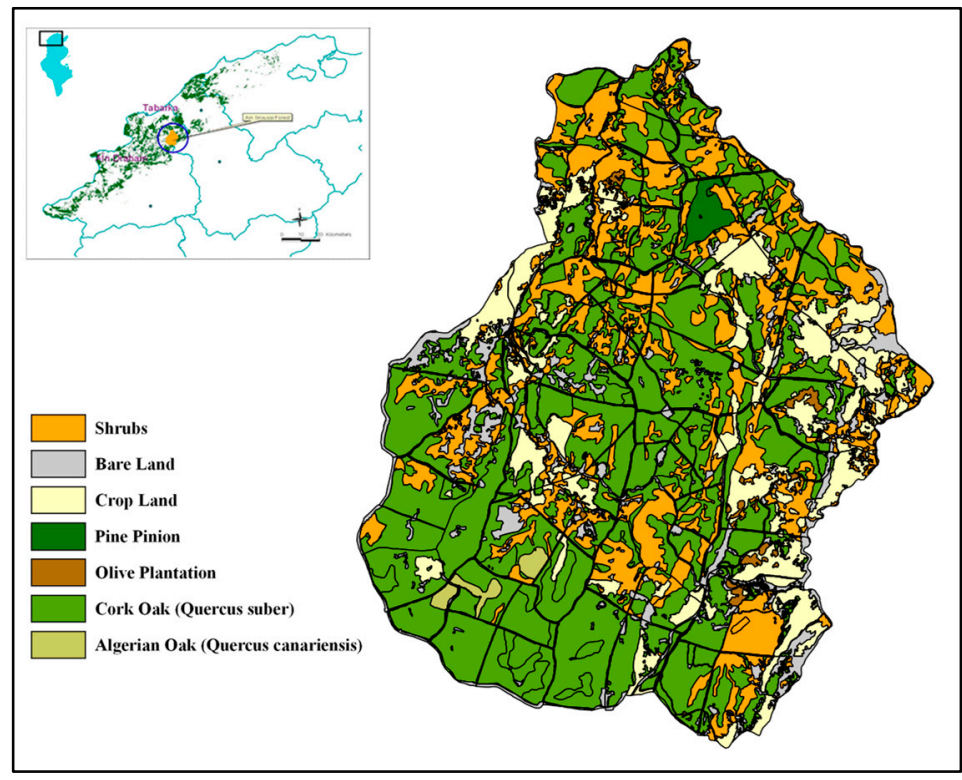

Figure 1. Land Cover and Location of Ain Snoussi forest, [24].

The study area is a transition zone between intense forest and wooded area, with 3787 ha comprising $50 \%$ cork oak, $24 \%$ shrubs, $13 \%$ cropland and olive trees and $10 \%$ of bare land as shown in Figure 1.

The region is characterized by a humid climate with a temperate winter presenting an average annual rainfall of $1000 \mathrm{~mm}$. The forest is also characterized by the existence of a local population living inside the forest, estimated at 1700 inhabitants in 2014 (according to the National Institute of Statistics). Despite the fact that cork oak forests are publicly owned, the local population benefits from free usage rights. The importance of the local population has been highlighted in several studies proving that local households are the main beneficiaries of the forest's economic value. According to Daly-Hassen and Ben Mansoura, 58\% of the net benefits in 2005 corresponded to the private economic value benefiting local users [25].

The forest is located upstream of the Sidi Barrak watershed. The water reservoir was created in 1999 and is used for three main puroses: drinking water supply, improvement of the water quality of the Medjerda Canal and irrigation; however, the actual use of the water collected in the watershed is drinking water.

According to the literature, the study site provides a multitude of goods and services, $[23,26,27]$. In the present work, classifications and definitions used were based on the Common International Classification of Ecosystem Services (CICES) explicit classification for consistency with the commonly used nomenclature. Differences between the land cover types in terms of management were considered; forests and shrubs are publicly managed, while olive plantations and crop lands are managed by the local population (making access to information more complicated). Only publicly managed land covers were studied.

\subsection{Biophysical Valuation Methods}

A multidisciplinary study was established to estimate the biophysical values of the ecosystem services provided in the area based on the most appropriate methods.

Table 1 shows the average production per ha and per year in 2016 and the corresponding biophysical method. The following ecosystem services were chosen to be studied for their importance, based on the literature review and on local experts' advices. 
Table 1. Investigated ecosystem services, average quantities and biophysical valuation methods.

\begin{tabular}{|c|c|c|c|c|c|}
\hline \multirow{2}{*}{ Ecosystem Service } & \multirow{2}{*}{$\begin{array}{c}\text { Unit } \\
\text { (per ha) }\end{array}$} & \multicolumn{3}{|c|}{ Average Quantity } & \multirow{2}{*}{$\begin{array}{c}\text { Biophysical } \\
\text { Valuation Method }\end{array}$} \\
\hline & & Shrubs & Clear Forest & Dense Forest & \\
\hline Sediment retention & $\mathrm{m}^{3}$ & 5.23 & 9.10 & 7.07 & RUSLE model \\
\hline Carbon sequestration & $\mathrm{T}$ & 0.11 & 1.24 & 2.16 & Biophysical models \\
\hline Grazing & FU & 639 & 550 & 363 & $\begin{array}{l}\text { Grazing potential per } \\
\text { land cover type }\end{array}$ \\
\hline $\begin{array}{l}\text { Reproductive } \\
\text { Virgin } \\
\text { Miscellaneous }\end{array}$ & Q & & $\begin{array}{l}0.81 \\
0.02 \\
0.03 \\
\end{array}$ & $\begin{array}{l}1.17 \\
0.05 \\
0.09 \\
\end{array}$ & $\begin{array}{l}\text { Average production } \\
\text { collected in } 12 \text { years }\end{array}$ \\
\hline Surface Area & ha & 920.00 & 816.38 & 1095.56 & \\
\hline
\end{tabular}

The cork production cycle is 12 years in Tunisia, resulting in "virgin cork" (cork bark harvested at the first bark stripping at age 30), "reproductive cork" (cork bark harvested in the following cycles) and "miscellaneous cork" (wasted cork after stripping). Forest administration is responsible for the harvest and sale of the product, allowing the availability of relevant quantities (in quintal) related to the product. Grazing average quantities per hectare were obtained from the pastoral inventory, determining grazing averages in FU per ha depending on cork oak forest density and recovery rate [28]. Stored carbon data was obtained from the estimation of annual tree and shrubs production giving average quantities per type of land cover and tree density in T/ha [24,29]. Sediment retention data were obtained via the revised universal soil loss equation (RUSLE) model results [30], based on rainfall, soil characteristics, topography, land use and land cover estimated at the watershed level.

\subsection{Total Economic Value and Economics Valuation Methods}

In North Tunisia, forest ecosystems are multifunctional and are known for being significant providers of goods and services. The focus on the assessment of the ecosystem services began in the early 21st century with the publication of the book "Valuing Mediterranean Forests: Towards Total Economic Value" in 2005, which was followed with an increasing interest up to the present day [23-28].

In this study, the methods used for economic valuation of the investigated ecosystem services were the market price method for carbon sequestration and cork, residual valuation method for grazing and the production function approach to determine the economic price for sediment retention. The market price method is the most commonly used method for valuation of ecosystem services when they are exchanged in a real market with observable prices assuming that there are no distortions [31,32]. The residual valuation method, also called residual imputation, is a technique used to determine the shadow price for non-market goods, obtained by subtracting all inputs costs from the total income. In the present case, the technique was applied to assess grazing value as an intermediate to local household income. The production function approach also called "environmental function" in the literature, focuses on measuring physical changes in output due to environmental change [12]. In specific cases, ecosystem services may be non-market such as the protection from damage and sediment retention. In such cases, the literature offers a suitable adaptation of the production function methodology in the form of the "expected damage function". In certain cases, when the ES is considered as a protection service limiting damages and providing individuals with benefits, the expected damage function (EDF) can be applied. According to Hanley, the approach is based on "the estimation of how changes in the asset affect the probability of the damaging event occurring", valuing the changes that might occur in quantities or qualities with respect to a non-market services using the consumer surplus approach [12]. The water demand function $(\mathrm{P})$ can be considered based on the following formula:

$$
\mathrm{P}=\exp ^{\wedge}((\ln ((\mathrm{Q}) / \varepsilon)+\mathrm{C})
$$


where $Q$ is water quantity, $\varepsilon$ the price elasticity, and $C$ is a constant.

Figure 2 presents the actual water demand curve. Assuming that sedimentation leads to a loss in quantity bringing the available water supply from $\mathrm{Q}$ to $\mathrm{Q}^{*}, \mathrm{P}^{*}$ is considered as the water economic price, defined as the amount a rational user is willing to pay for it.

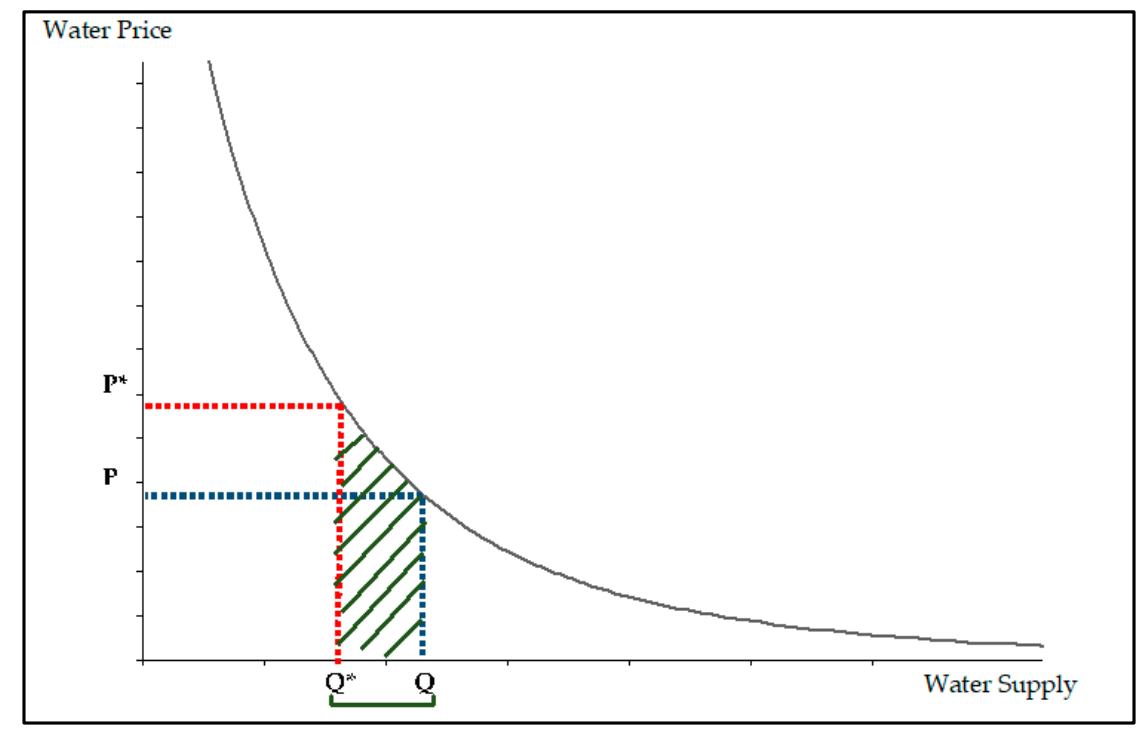

Figure 2. Water demand function.

\subsection{Mapping and Spatial Distribution}

The interest in spatial ecosystem assessment has increased in the recent years, being applied for the integration of spatial ES assessment data into planning, decision-making, or even management contexts. Such techniques reinforce the trend toward the multidisciplinary, aiming to combine the assessment of biophysical, economic, and social context when taking into consideration the spatial distribution of ES. Considered an effective communication tool, spatial assessment is based on the illustration of ecosystem services' provision, and sometimes of trade-offs at different scales [33]. The mapping technique has been described as a powerful tool for integrating complex information related to ecosystem services into decision-making and for combining results to identify proprietary action regions [34]. The need for spatially explicit mapping and assessment can be explained by the need to understand the level at which the natural processes occur [35]. However, besides the accuracy of the information provided by the initial mapping technique, there is a need for a higher integration of the results in order to reach the ultimate objective "decision-making guidance" [33].

More recently, decision-making support tool have been based on a combination of mapping and modeling tools, which vary depending on the valuation approach used, the geographical scale, and the range of the considered ES (individual or portfolios) [36].

\subsection{Management Scenarios}

In the framework of the INFORMED project, the social component was considered as important as the economic and biophysical component. The study area is a particular case of a situation with conflict between different stakeholders, since property rights for the forest and shrubs are detained by the state and managed by the forest administration while usage rights are detained by the local population. Agricultural lands (crop land and olive plantations) are privately owned. In the present study, besides estimation of the total economic value to point the economic importance of cork oak forest in North Tunisia with emphasis on different land covers, an evaluation of new management scenarios toward a better decision-making orientation was made. Only shrubs and cork oak stands were considered as land cover types, while carbon sequestration, sediment retention, cork and grazing 
were studied as ecosystem services provided. A distinction between two types of cork oak stands was made based on density. A forest was assumed to be dense when the density was higher than 317 tree/ha (considered as the maximum limit for optimal cork production [24]) and/or the forest recovery rate was higher than $50 \%$.

Two scenarios were suggested besides the business as usual scenario (BAU). The first was proposed by researchers based on the water scarcity situation and the productivity of cork oak stands, while the second scenario was more conservative towards the cork oak forest, proposed by the public authorities aiming to increase forest surface area.

\section{Scenario 1: Forest Density Decrease}

Scenario 1 was based on the decrease in forest density. In areas where the forest was considered dense (density $>317$ tree/ha), the stands were cleared to reach an average optimal density of 300 tree/ha.

\section{Scenario 2: Afforestation of Shrub Area}

The scenario 2 was based on the replacement of shrub area with new plantations of cork oak. The new plantation took the average value of the total economic value provided by the clear forest.

\section{Results}

\subsection{Economic Valuation}

The provisioning and regulation services prices were either calculated or estimated as follows. Cork is a market good. The cork production value of the 2016 estimated from the forest administration data gave: $€ 61.5 / Q$ for reproductive cork, $€ 13 / Q$ for the virgin cork, and $€ 22.95 / Q$ for the miscellaneous cork. The operating average cost was estimated at $€ 26.1 / Q$, is deducted from the obtained net profit of the cork production. Grazing has no observable price, and the valuation was later derived by applying the residual value of the forage unit, estimate at $€ 0.19 / F U$. For carbon sequestration, the economic valuation was processed through the application of the 2016 economic price for emissions reduction, to the annual average carbon flux. Regarding sediment retention, the valuation was carried out applying the economic price of water, based on the Tunisian national water distribution utility data [37] and water price elasticity [38], assuming a constant price elasticity of demand along the curve to solve the water demand function (Equation (1)). Considering potable water as the main use of the water from the watershed, the sediment retention service was valued by applying the water economic price at $€ 0.274 / \mathrm{m}^{3}$, resulting from the application of the demand function model. The value of sediments retained in terms of water capacity was then estimated, applying a discount rate of $2 \%$ for a period of 30 years $[9,23,39]$.

\subsection{Total Economic Value of the Investigated Services}

The results showed that the total economic value of the total area of Ain Snoussi (cork oak Forest (clear and dense) and shrubs) is estimated at $€ 0.55$ million/year, obtained as follows: $40 \%$ from regulating services (21\% form sediment retention and 19\% from carbon sequestration and $60 \%$ from provisioning services (50\% from grazing, 11\% from cork). Figure 3 shows the distribution of the TEV across the land cover types. Grazing provides the highest value for all the land cover types with $79 \%$ for shrubs, $48 \%$ for clear forest and 33\% for dense forest, followed by sediment retention providing $24 \%$ of the TEV of clear forests and $19.3 \%$ and $19.2 \%$ for shrubs and dense forests, respectively. Carbon sequestration contributes up to $30 \%$ of the TEV of the dense forests, $17 \%$ for the clear forests, and $2 \%$ for shrubs. Cork gives the lowest percentage of the TEV, with $17 \%$ for dense forests and $11 \%$ for clear forests.

Table 2 summarizes the biophysical flows and the economic value of the selected ecosystem services provided by the cork oak forest (dense and clear) and shrubs in Ain Snoussi, and the average of economic value in Euro per ha per year for each land cover type.

The provisioning services valuation accounted for around $€ 0.33$ million/year, provided mainly by the estimated grazing and the average annual production of cork (considered by public authorities 
as the main product of the area, as it is a market product). Regulation services, in terms of sediment retention and carbon flow, accounted for $€ 0.21$ million/year. The total economic value TEV, was the sum of the estimated ecosystem services in the cork oak forest and shrubs of Ain Snoussi, evaluated at $€ 0.55$ million/year, giving an average TEV of $€ 194 /$ ha/year. With $€ 0.41$ million/year of total economic value at cork-oak forest level, the importance of the ecosystem services provided in the area and, more precisely the non-market services that are commonly underestimated is highlighted. Knowing the TEV of the cork oak forest, may hint the importance of the ecosystem and can be used as a solid argument for management and conservation, and mainly highlights the important differences between clear forest and dense forest. However, this knowledge is not enough to create targeted action.

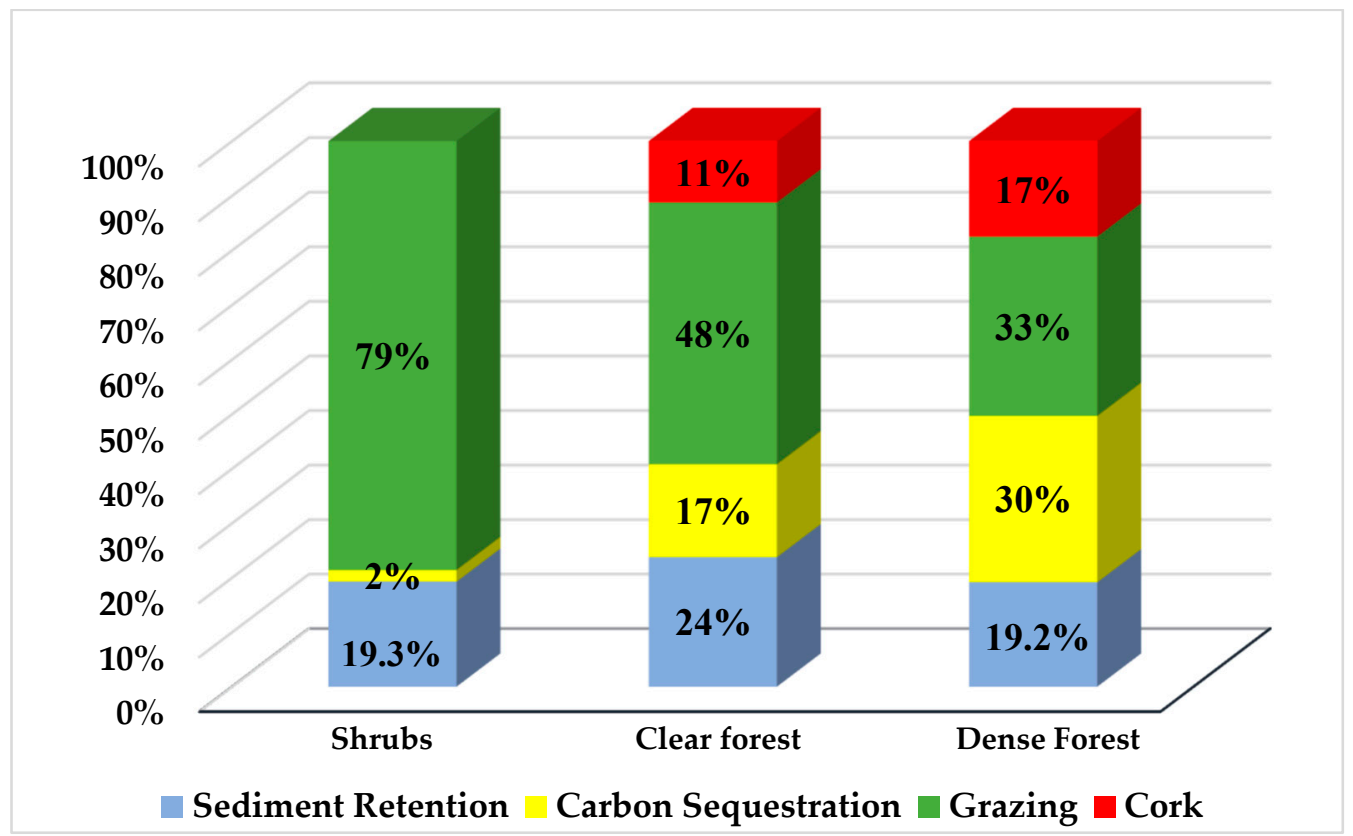

Figure 3. Distribution of the total economic value by land cover type.

Table 2. Total and average economic values of ecosystem services per land cover type in Ain Snoussi cork oak forest in 2016.

\begin{tabular}{|c|c|c|c|c|c|}
\hline \multirow{2}{*}{ Ecosystem Service } & \multicolumn{3}{|c|}{ TEV per Land Cover Type (Millions of $€$ ) } & \multirow{2}{*}{$\begin{array}{c}\text { Total Forest (Clear } \\
\text { and Dense) }\end{array}$} & \multirow{2}{*}{$\begin{array}{l}\text { TEV Ain Snoussi } \\
\text { (Millions of } € \text { ) }\end{array}$} \\
\hline & Shrubs & Clear Forest & Dense Forest & & \\
\hline Sediment Retention & 0.027 & 0.04 & 0.04 & 0.09 & 0.11 \\
\hline Carbon Sequestration & 0.003 & 0.03 & 0.07 & 0.10 & 0.10 \\
\hline Grazing & 0.11 & 0.09 & 0.08 & 0.16 & 0.27 \\
\hline Cork & & 0.02 & 0.04 & 0.06 & 0.06 \\
\hline Total Value (Millions of $€$ ) & 0.14 & 0.18 & 0.23 & 0.41 & 0.55 \\
\hline Surface Area (ha) & 920.00 & 816.38 & 1095.564 & & 2831.94 \\
\hline Average Value (€/ha) & 154.5 & 217.7 & 210.2 & - & 194.3 \\
\hline
\end{tabular}

A spatial distribution of the average TEV of the cork-oak forest was obtained by computing unitary ecosystem services values per ha. The results showed a variation between $€ 122$ and $€ 267$ per ha per year for the dense forest, with an average TEV of $€ 210$ and a variation between $€ 166$ and $€ 292$ per ha and per year for the clear forest, with an average of $€ 217$ (Figure 4).

The same figure shows the spatial distribution of the average economic value of shrubs with a variation between $€ 128$ and $€ 278$ per ha per year, with an average of $€ 157$ for all the parcels larger than 1 ha. 


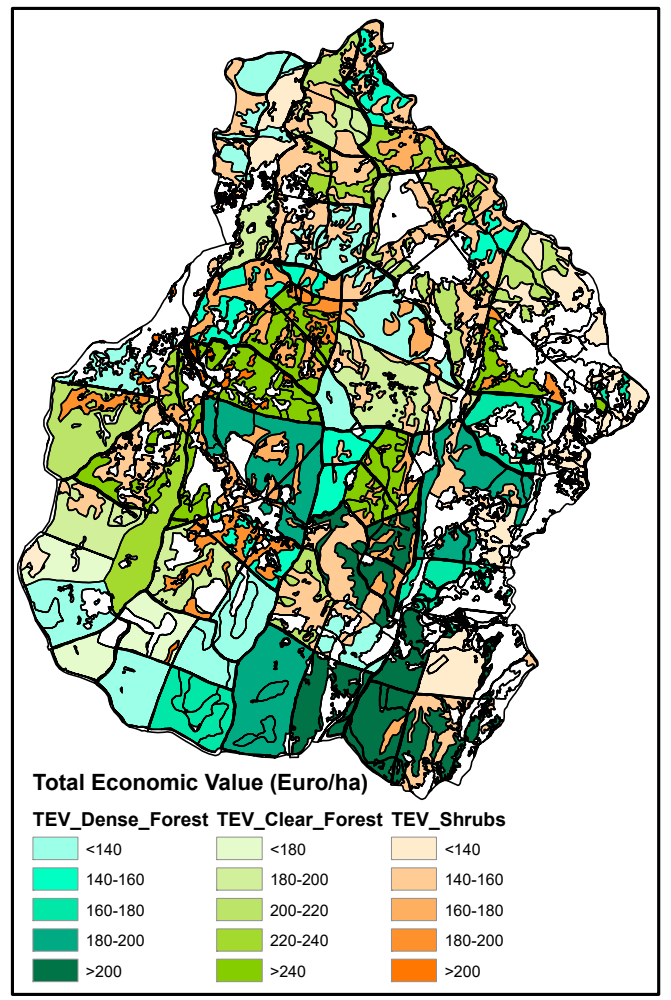

Figure 4. Spatial distribution of the total economic value.

\subsection{Management Scenarios Results}

Cork-oak clear and dense forest and shrubland were considered for the evaluation of a new management plan. For decision-making support purposes, two scenarios were evaluated to check which scenario was the most valuable (Table 3).

The estimation of the two previously described scenarios showed that the second scenario based on afforestation of the shrub area, provided the highest TEV ( $€ 0.68$ million/year) compared to both BAU ( $€ 0.55$ million/year) and the first scenario based on density decrease ( $€ 0.54$ million/year) (Table 3).

The first scenario had a slight effect on the ecosystem services, with a change in 1095 ha of cleared cork oak surface bringing density to 300 ha. The change led to a decrease of $2 \%$ in the total economic value. The scenario negatively affected both carbon sequestration and cork, an effect that can be explained by the decrease in the number of trees, while for grazing and sediment retention, a remarkable increase was noticed with $14 \%$ and $40 \%$, respectively. This increase can be explained by the negative correlation of grazing with forest density (the higher the density, the lower the grazing value per forage unit). For sediment retention, the results could be interpreted based on the initial biophysical results, which showed that the clear forest sediment retention was higher than dense forest sediment retention. The results can be explained by two major biophysical factors: the variation of the elevation and the recovery rate of the impacted area. The second scenario led to a larger impact with an increase of $24 \%$ in the TEV. The afforestation scenario had a considerable positive impact on cork $(37 \%)$, carbon sequestration $(30 \%)$, and sediment retention $(83 \%)$. Only the grazing service was negatively impacted, with a decrease of $6 \%$.

The spatial distribution (Figure 5) showed the exact geolocation for each scenario and the remaining and the new economic value for each area affected by the transition. The first scenario, homogenous forest area with a density lower than 317 tree/ha, presented an average TEV of $€ 207 /$ ha and no change for the shrub area. The second scenario showed the appearance of a new plantation replacing the shrub area with an average TEV of $€ 218 /$ ha (average TEV of the clear forest for the BAU). 
Table 3. Total and average economic values per hectare and per ecosystem services for two different scenarios.

\begin{tabular}{|c|c|c|c|c|c|c|}
\hline \multicolumn{7}{|c|}{ Scenario 1: Forest Density Decrease } \\
\hline & \multicolumn{4}{|c|}{ TEV per Land Cover (Millions of $€ /$ year) } & \multirow{2}{*}{$\begin{array}{c}\text { TEV } \\
\text { (Millions of } € \text { ) }\end{array}$} & \multirow{2}{*}{$\begin{array}{c}\text { Difference } \\
\text { to BAU }\end{array}$} \\
\hline & Shrubs & Clear Forest & Dense Forest & New Plantation & & \\
\hline Sediment Retention & 0.03 & 0.13 & - & - & 0.16 & $40 \%$ \\
\hline Carbon Sequestration & 0.003 & 0.07 & - & - & 0.07 & $-33 \%$ \\
\hline Grazing & 0.11 & 0.20 & - & - & 0.31 & $14 \%$ \\
\hline Cork & - & 0.05 & - & - & 0.05 & $-22 \%$ \\
\hline TEV (Millions of $€$ ) & 0.14 & 0.40 & - & - & 0.54 & $-2 \%$ \\
\hline Surface Area (ha) & 920.0 & 1911.9 & - & - & 2831.94 & - \\
\hline Average Value (€/ha) & 157.4 & 207.2 & 191.02 & - & 157.4 & - \\
\hline \multicolumn{7}{|c|}{ Scenario 2: Afforestation of Shrub Area } \\
\hline Sediment Retention & - & 0.05 & 0.11 & 0.05 & 0.21 & $83 \%$ \\
\hline Carbon Sequestration & - & 0.03 & 0.07 & 0.03 & 0.13 & $30 \%$ \\
\hline Grazing & - & 0.09 & 0.08 & 0.10 & 0.26 & $-6 \%$ \\
\hline Cork & - & 0.02 & 0.04 & 0.02 & 0.08 & $37 \%$ \\
\hline TEV (Millions of $€$ ) & - & 0.18 & 0.30 & 0.20 & 0.68 & $24 \%$ \\
\hline Surface Area (ha) & - & 816.38 & 1095.56 & 920.00 & 2831.94 & - \\
\hline Average Value (€/ha) & - & 222.70 & 274.62 & 217.81 & 241.19 & - \\
\hline
\end{tabular}
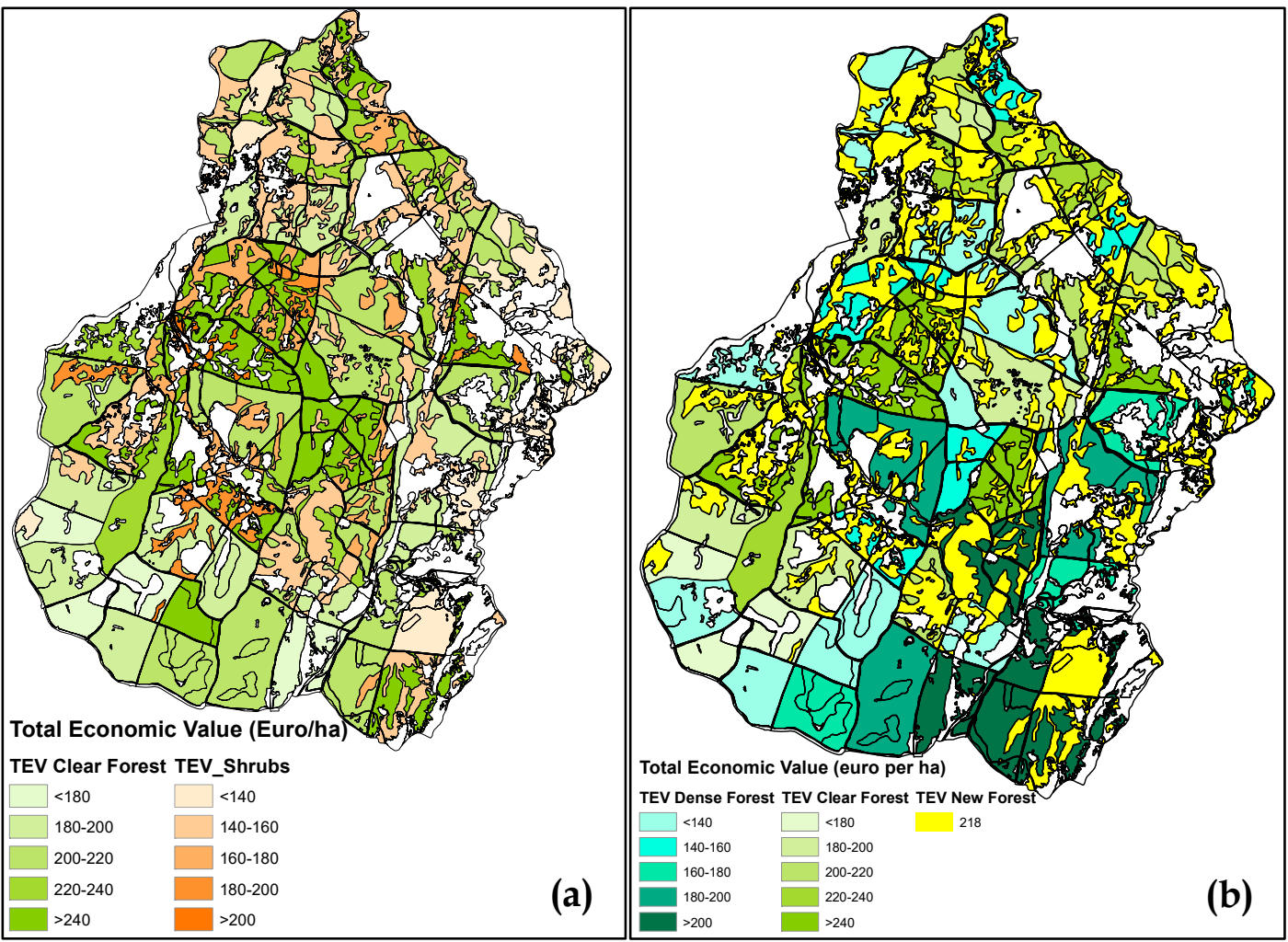

Figure 5. Spatial distribution of average total economic value for management scenarios: (a) scenario 1: forest density decrease; (b) Scenario 2: afforestation of shrubs area.

\section{Discussion}

This study investigated both the biophysical flows and economic value of a cork oak ecosystem services with emphasis on the spatial distribution. Tunisian forests are particularly vulnerable to change and degradation risks, due to their location on the southern side of the Mediterranean basin and exposure to climate change [40] from one side, and the presence of the local population and the pressure they are exerting [26] from the other side. The actual study answered several questions and 
addressed doubts about the actual situation of cork oak forests in Tunisia and the potential management scenarios. However, the restricted number of the ecosystem services investigated due to data limitation was a serious constraint.

Remaining faithful to the original concept behind valuation of ES, monetary valuation was applied in this study as a tool to capture the benefits human may receive from nature, which can be underestimated due to their non-market characteristics. The assessment showed that the average total economic value of $€ 194 /$ ha was higher than the average TEV in Tunisian cork oak forest given by the most recent study of 2010, which reported $€ 160 /$ ha (305.4 TND/ha in 2010) [41], proving that at least during the last past 5 years, no degradation has occurred in the study area and indicating an increase in the total value.

To preserve this resource and to support decision-making toward sustainable management, the valuation of two management scenarios was carried out based on the suggestion of the forest administration to increase the forest area by replacing the shrub lands, and on the suggestion of researchers to decrease the forest density. Scenario 1 showed that decreasing forest density would lead to a decrease in the total value of the forest with $2 \%$, while the second scenario based on afforestation would allow a significant increase of the TEV with $24 \%$. The process of distinguishing two types of forest makes the management suggestions more precise and clear. Considering that management is usually based on biophysical objectives and that the forest is divided into parcels, a land cover change can be suggested based on values and geographic distribution.

Based on the latest Tunisian Sustainable Development Strategy 2015-2024, the national policy is oriented towards sustainable management, taking into consideration the existence of the local population and aiming to solve an ancestral conflict and an institutional issue [42-44]. To align with these, the results of this study should be discussed between the three stakeholders initially implicated in the elaboration of the studied scenarios.

Such results can be used to make accurate and precise management plans to face and prevent anthropogenic and non-anthropogenic hazards, and to warn decision-makers. The spatial distribution of economic value by land cover type and ecosystem service is a new tool that may facilitate future planning and management of such stands, suggesting a change in certain areas. However, two constraints should be taken into consideration at this level: first, that such results are sensitive to the chosen methods, and secondly that these results are specific to this case study; thus, excessive generalization may be harmful to biodiversity. The impacts of such scenarios on local populations and their social acceptance also need to be investigated.

\section{Conclusions}

The present work showed the total economic value of a set of investigated of ecosystem services provided by the cork-oak forest in Ain Snoussi and highlighted the importance of the supplied services in terms of market and non-market products. Mapping ecosystem services allows a deeper and more explicit understanding and a clearer visualization of the spatial distribution of total economic value, and of individual services in terms of biophysical and economic values.

The results also showed that spatially distributed value can be used as a strong tool with which to assess management scenarios and guide decision-makers. The chosen example of management scenarios showed that for the Ain Snoussi forest area, increasing the forest stand by planting the shrub area is the most valuable scenario; however a cost-benefit analysis needs to be carried out in order to return more relevant results.

Author Contributions: M.K. and H.D.-H. were responsible for the overall design of the study, the methodology, the interpretation of the results, and the writing of the paper. B.S. and S.J. were responsible of the biophysical models and made significant contributions in the scenarios elaboration and maps design. All authors have read and agreed to the published version of the manuscript. 
Funding: This research was funded by the Institution for Agricultural Research and Higher Education (IRESA)-Ministry of Agriculture, Water Resources and Fisheries, Tunisia and the European Union Horizon 2020 program, under Faster project, grant agreement $\mathrm{N}^{\circ}$ (810812).

Acknowledgments: The authors acknowledge helpful funding from the European Union Horizon 2020 program, under Faster project, grant agreement $\mathrm{N}^{\circ}$ (810812).

Conflicts of Interest: The authors declare no conflict of interest. The funders had no role in the design of the study; in the collection, analyses, or interpretation of data; in the writing of the manuscript, or in the decision to publish the results.

\section{References}

1. Westman, W.E. How much are nature's services worth. Science 1977, 197, 960-963. [CrossRef] [PubMed]

2. Gómez-Baggethun, E.; de Groot, R.; Lomas, P.L.; Montes, C. The history of ecosystem services in economic theory and practice: From early notions to markets and payment schemes. Ecol. Econ. 2010, 69, 1209-1218. [CrossRef]

3. De Groot, R.; Brander, L.; van der Ploeg, S.; Costanza, R.; Bernard, F.; Braat, L.; Christie, M.; Crossman, N.; Ghermandi, A.; Hein, L.; et al. Global estimates of the value of ecosystems and their services in monetary units. Ecosyst. Serv. 2012, 1, 50-61. [CrossRef]

4. Pascual, U.; Balvanera, P.; Díaz, S.; Pataki, G.; Roth, E.; Stenseke, M.; Watson, R.T.; Başak Dessane, E.; Islar, M.; Kelemen, E.; et al. Valuing nature's contributions to people: The IPBES approach. Curr. Opin. Environ. Sustain. 2017, 26-27, 7-16. [CrossRef]

5. Danley, B.; Widmark, C. Evaluating conceptual definitions of ecosystem services and their implications. Ecol. Econ. 2016, 126, 132-138. [CrossRef]

6. Ehrlich, P.; Ehrlich, A. Extinction. The Causes and Consequences of the Disappearance of Species. Q. Rev. Biol. 1982, 57, 343.

7. Ehrlich, P.R.; Mooney, H.A. Extinction, Substitution, and Ecosystem Services. Bioscience 1983, 33, $248-254$. [CrossRef]

8. Costanza, R.; Arge, R.; De Groot, R.; Farberk, S.; Grasso, M.; Hannon, B.; Limburg, K.; Naeem, S.; O’Neill, R.V.; Paruelo, J.; et al. The value of the world's ecosystem services and natural capital. Nature 1997, 387, 253-260. [CrossRef]

9. Merlo, M.; Croitoru, L. Valuing Mediterranean Forests: Towards Total Economic Value; CABI Publishing: Wallingford, UK, 2005; ISBN 0851999972.

10. Heal, G.M.; Barbier, E.B.; Boyle, K.J.; Covich, A.P.; Gloss, S.P.; Hershner, C.H.; Hoehn, J.P.; Pringle, C.M.; Polasky, S.; Segerson, K.; et al. Valuing Ecosystem Services: Toward Better Environmental Decision-Making; THE NATIONAL ACADEMIES PRESS: Washington, DC, USA, 2005; ISBN 978-0-309-09318-7.

11. Turner, R.K.; Daily, G.C. The Ecosystem Services Framework and Natural Capital Conservation; Springer: Dordrecht, The Netherlands, 2008; Volume 39.

12. Hanley, N.; Barbier, E.B. Pricing Nature: Cost-benefit Analysis and Environmental Policy; Edward Elgar Publishing: London, UK, 2009; ISBN 184980205X.

13. Millennium Ecosystem Assessment. Ecosystems and Human Well-Being: Synthesis; Island Press: Washington, DC, USA, 2005; ISBN 1-59726-040-1.

14. Kumar, P. The Economics of Ecosystems and Biodiversity: The Ecological and Economic Foundations; Earthscan: London, UK; Washington, DC, USA, 2009.

15. De Groot, R.S.; Wilson, M.A.; Boumans, R.M.J. A typology for the classification, description and valuation of ecosystem functions, goods and services. Ecol. Econ. 2002, 41, 393-408. [CrossRef]

16. Boyd, J.; Banzhaf, S. What are ecosystem services? The need for standardized environmental accounting units. Ecol. Econ. 2007, 63, 616-626. [CrossRef]

17. Wallace, K.J. Classification of ecosystem services: Problems and solutions. Biol. Conserv. 2007, 139, 235-246. [CrossRef]

18. Fisher, B.; Turner, R.K.; Morling, P. Defining and classifying ecosystem services for decision making. Ecol. Econ. 2009, 68, 643-653. [CrossRef]

19. Ojea, E.; Martin-Ortega, J.; Chiabai, A. Defining and classifying ecosystem services for economic valuation: The case of forest water services. Environ. Sci. Policy 2012, 19-20, 1-15. [CrossRef] 
20. Haines-young, R.; Potschin, M. Common International Classification of Ecosystem Services (CICES); European Environment Agency: Nottingham, UK, 2013.

21. IPBES Preliminary Guide Regarding Diverse Conceptualization of Multiple Values of Nature and Its Benefits, Including Biodiversity and Ecosystem Functions and Services; Intergovernmental Science-Policy Platform on Biodiversity and Ecosystem Services: Bonn, Germany, 2015.

22. Tardieu, L. The need for integrated spatial assessments in ecosystem service mapping. Rev. Agric. Food Environ. Stud. 2017, 98, 173-200. [CrossRef]

23. FAO (Food and Agriculture Organization of The United Nations). DGF (Direction Générale des Forêts), Evaluation économique des biens et services des forêts tunisiennes; Daly-Hassen, H., Croitoru, L., Tounsi, K., Aloui, A., Jebari, S., Eds.; Food and Agriculture Organization: Rome, Italy, 2012.

24. Stiti, B. Analyse du potentiel de croissance et de production dans une forêt de chêne-liège en Kroumirie. Ph.D. Thesis, Université Tunis El Manar Faculté, Tunis, Tunisia, 2017.

25. Daly-hassen, H.; Mansoura, A. Ben Private and Social Values derived from a Tunisian cork oak agroforestry production system. In Proceedings of the XIII World Forestry Congress, Nairobi, Kenya, 23-28 August 2009; p. 11.

26. Chebil, A.; Ovando, P.; Daly-Hassen, H. Total commercial income from a cork oak forest agroforestry system in the region of Iteimia. In Cork Oak Woodlands and Cork Industry: Present, Past and Future; Museu del Suro de Palafrugell: Palafrugell, Spain, 2009; pp. 514-535.

27. Campos, P.; Daly-Hassen, H.; Ovando, P. Cork oak forest management in Spain and Tunisia: Two case studies of conflicts between sustainability and private income. Int. For. Rev. 2007, 9, 610-626. [CrossRef]

28. Direction Générale des Forêts Résultats du premier inventaire pastoral national en Tunisie; DGF Tunisie: Tunis, Tunisia, 1995.

29. Sebei, H.; Chaar, H.; Stiti, B.; Montero, G. Evaluation of the aboveground biomasses of cork oak (Quercus suber). In Cork Oak Woodlands and Cork Industry: Present, Past and Future; Zapato, S., Ed.; Museu del Suro de palafrugell: Girona, Spain, 2009; p. 170.

30. Data Were Obtained as Results of Hydrological Modeling, Obtained from Work Package Activities in the Framework of the "Integrated Research on Forest Resilience and Management in the Mediterranean" (INFORMED) Project (2015-2017). Available online: https://www6.inrae.fr/informed-foresterra_eng (accessed on 31 December 2019).

31. Ovando, P.; Caparrós, A.; Diaz-Balteiro, L.; Pasalodos, M.; Beguería, S.; Oviedo, J.L.; Montero, G.; Campos, P. Spatial Valuation of Forests' Environmental Assets: An Application to Andalusian Silvopastoral Farms. Land Econ. 2017, 93, 87-108. [CrossRef]

32. Croitoru, L. Valuing the non-timber forest products in the Mediterranean region. Ecol. Econ. 2007, 63, 768-775. [CrossRef]

33. Malinga, R.; Gordon, L.J.; Jewitt, G.; Lindborg, R. Mapping ecosystem services across scales and-A review. Ecosyst. Serv. 2015, 13, 57-63. [CrossRef]

34. Häyhä, T.; Franzese, P.P.; Paletto, A.; Fath, B.D. Assessing, valuing, and mapping ecosystem services in Alpine forests. Ecosyst. Serv. 2015, 14, 12-23. [CrossRef]

35. Tammi, I.; Mustajärvi, K.; Rasinmäki, J. Integrating spatial valuation of ecosystem services into regional planning and development. Ecosyst. Serv. 2017, 26, 329-344. [CrossRef]

36. Pandeya, B.; Buytaert, W.; Zulkafli, Z.; Karpouzoglou, T.; Mao, F.; Hannah, D.M. A comparative analysis of ecosystem services valuation approaches for application at the local scale and in data scarce regions. Ecosyst. Serv. 2016, 22, 250-259. [CrossRef]

37. National Water Distribution Utility Sonede. Available online: http://www.sonede.com.tn/index.php?id=12\& $\mathrm{L}=2$ (accessed on 4 October 2019).

38. Ben Zaied, Y.; Ben Cheikh, N.; Nguyen, P. Modeling nonlinear water demand: The case of Tunisia. Econ. Bull. 2017, 37, 637-644.

39. Potthast, M.; Daly-hassen, H.; Gader, G. Analyse de la vulnérabilité des écosystèmes forestiers tunisiens face au changement climatique et conséquences socio-économiques associées; Gesellschaft für Technische Zusammenarbeit (GIZ): Bonn, Germany, 2005.

40. European Environment Agency. Climate Change, Impacts and Vulnerability in Europe 2012; European Environment Agency: Copenhagen, Denmark, 2012. 
41. Daly-Hassen, H.; Gader, G.; Potthast, M.C. Une approche économique pour choisir les options d ' adaptation des forêts au changement climatique: Application à la forêt de chêne liège en Tunisie. In Proceedings of the XIVème Congrès Forestier Mondial, Durban, South Africa, 7-11 September 2015.

42. Ben Mansoura, A.; Garchi, S.; Daly, H. Analyzing forest users' destructive behavior in Northern Tunisia. Land Use Policy 2001, 18, 153-163. [CrossRef]

43. World Bank Group/DGF (Direction Générale des Forêts). Stratégie de développement durable des forêts et des parcours en Tunisie 2015-2024; The World Bank Group: Washington, DC, USA, 2015.

44. Indufor Oy. Indufor Financing for Sustainable Forest Management in Tunisia; Country Case Study Prepared by H. Daly; Indufor Oy: Helsinki, Finland, 2012.

(C) 2020 by the authors. Licensee MDPI, Basel, Switzerland. This article is an open access article distributed under the terms and conditions of the Creative Commons Attribution (CC BY) license (http://creativecommons.org/licenses/by/4.0/). 